\title{
CHROMOSOME DAMAGE IN CULTURED BOVINE PERIPHERAL LYMPHOCYTES INDUCED BY HERBICIDE CHLORIDAZON
}

\author{
K. ŠIVIKOVÁ, J. DIANOVSKÝ, E. PIEŠOVÁ \\ Department of Veterinary Genetics, University of Veterinary Medicine, \\ Košice, Slovak Republic \\ Received November 11, 1998 \\ Accepted March 31, 1999
}

Abstract

Šiviková K., J. Dianovský, E. Piešová: Chromosome Damage in Cultured Bovine Peripheral Lymphocytes Induced by Herbicide Chloridazon. Acta Vet. Brno 1999, 68: 105-110.

Herbicide chloridazon was tested for its ability to induce micronuclei (MN), chromosome aberrations (CA) and sister chromatid exchanges (SCE) as well as for its influence on cell cycle kinetics in cultured bovine peripheral lymphocytes. To detect possible metabolic modifications in herbicide genotoxicity, the cultures for the SCE determination were also treated with S9 fraction.

Significant elevations of CA and $\mathrm{MN}$ were found in cultures treated with chloridazon at a dose of $7 ¥ 10^{-4} \mathrm{~mol} \cdot \mathrm{l}^{-1}(\mathrm{P}<0.05$ or $\mathrm{P}<0.01$, respectively) but no increase of these endpoints were seen with both lower doses $\left(7 \times 10^{-5}\right.$ and $\left.7 ¥ 10^{-6} \mathrm{~mol} \cdot 1^{-1}\right)$. Clear dose dependence and statistically significant increases in induced chromosome damage were observed in the SCE assay without use of S9 fraction. The highest concentration tested caused also a reduction of the proliferation index and a weak proliferation delay.

These positive results provide information about the possible genetic risk increase for humans through the food chain.

Chloridazon, bovine peripheral lymphocytes, sister chromatid exchanges, chromosome aberrations, micronuclei

In recent years pesticide toxicity has been extensively investigated. The reason for this is not only their important role in agriculture but especially findings that certain pesticides showed carcinogenic and mutagenic properties in laboratory animals and exposed humans (Dolara et al. 1992; Hrelia et al. 1996; Woo et al. 1996).

Among pesticides, herbicides are widespread in the environment because most of them have been usually applied directly into the soil. Chloridazon is a herbicide currently used for selective control in beets. It belongs to the class of Hill reaction inhibitors (Cre mlyn 1978; Corbett et al. 1984). Several reports deal with the genotoxic effects of commonly used herbicides, e. g. alachlor, trifluralin and maleic hydrazide (Ribas et al. 1996ab) but no evidence of cytogenetic or genotoxic effects of chloridazon has been shown.

Previously we reported our results from cytogenetic studies with chloridazon treated sheep blood lymphocytes (Šiviková and Dianovský 1997). We confirmed the sensitivity of sheep lymphocytes to chloridazon exposure in the sister chromatid exchange assay.

To obtain additional data and to extend the information on the genotoxicity of chloridazon we report here our results on the induction of chromosomal aberrations (CA), micronuclei $(\mathrm{MN})$ and sister chromatid exchanges (SCE) in cultured bovine peripheral lymphocytes. There are mentions that cattle is a very sensitive species of domestic animals with regard to exposure and accumulation of chemical agents (Hadač 1989). Ruminants can be exposed to various environmental mutagens via pasture. Thus they represent a suitable model for evaluating the genotoxicity of environmental pollutants with predictive value for human health risk.

Address for correspondence:

RNDr. Katarína Šiviková, CSc.

Department of Veterinary Genetics,

Komenského 73,041 81 Košice, Slovak Republic
Phone: +421956332111 , (ext. 482)

Fax: +421 956323666

http://www vfu.cz/acta-vet/actavet.htm 
Chloridazon (5-amino-4-chloro-2-phenylpyridazin-3 (2H)-one, Istrochem, Slovak Republic, 92,6\% purity) was soluble in dimethyl sulfoxide (DMSO, Sigma, St. Louis, MO, USA) and freshly prepared at concentrations of 7x10 $0^{-6}$, $7 \times 10^{-5}$ and $7 \times 10^{-4} \mathrm{~mol} \cdot \mathrm{l}^{-1}$ before each experiment. The final DMSO concentration in treated and control cultures was $0.05 \%$.

Mitomycin C (MMC, Sigma, St. Louis, MO, USA), ethylmethanesulfonate (EMS, Sigma, St. Louis, MO, USA) and cyclophosphamide (CPA, Jenapharm, Ankerwerk, Rudolstadt, Germany) were used as positive control agents in the absence and in the presence of the metabolic activation ( $\mathrm{S} 9 \mathrm{mix}$ ), respectively.

Experiments were carried out with two healthy cow donors (Slovak spotted cattle, 3-months-old). For SCE assays, experiments were made both in the presence and in the absence of S9 mix. A freshly prepared S9 fraction ( $10 \%$ of the culture volume) from Aroclor 1254 (Supelco, Bellefonte, PA, USA) induced male mice was prepared according to the method of Maron and Ames (1983) and used in control and experimental cultures with glucose-6-phosphate cofactors (Aldrich, Milwaukee, WI, USA) and NADP (Sigma, St. Louis, MO, USA).

Cell cultivation

Whole blood cultures $(0.5 \mathrm{ml})$ were cultivated for $72 \mathrm{~h}$ at $38^{\circ} \mathrm{C}$ in $10 \mathrm{ml}$ of RPMI 1640 medium supplemented with $15 \%$ fetal calf serum, antibiotics (penicillin $250 \mathrm{U} / \mathrm{ml}$ and streptomycin $250 \mathrm{~m} \mathrm{~g} / \mathrm{ml}$ ), and phytohaemagglutinin (PHA, $180 \mathrm{~m}$ g/ml, Welcome, Darford, England).

Chromosome preparations for CA and SCE assays were obtained by the standard cytogenetic method; $2 \mathrm{~h}$ before harvest colchicine (Merck, Darmstadt, Germany) was added at a concentration of $5 \mathrm{~m} \mathrm{~g} / \mathrm{ml}$. The lymphocyte cultures without S9 fraction were exposed to chloridazon for the last $24 \mathrm{~h}$ of cultivation, while cultures with S9 were treated with herbicide for $1.5-2 \mathrm{~h}$, then the cells were removed and replaced in fresh medium.

For the MN assay Cytochalasin B (Cyt. B, Sigma, St. Louis, MO, USA) was added at $44 \mathrm{~h}$ after start of the culture at a concentration of $3 \mathrm{~m} \mathrm{~g} / \mathrm{ml}$. The tested substance was added $24 \mathrm{~h}$ after culture initiation and was present until the end of cultivation (Watt and Stephen 1986; Surrallés et al. 1995). The herbicide treatment for $48 \mathrm{~h}$ is recommended to achieve an accumulation of MNi (Almássy et al. 1987).

For the SCE assay and the cell cycle kinetics bromodeoxyuridine $(8 \mathrm{~m} \mathrm{~g} / \mathrm{ml}$, BrdUrd, Sigma, St. Louis, MO, USA) was added to all cultures $24 \mathrm{~h}$ after initiation of division. Slides were stained with Giemsa for CAs and MNi or FPG technique to differentiate sister chromatids and cell cycles (Perry and Wolff 1974).

One thousand of binucleated (BN) cells per donor and concentration were analysed for MNi and one hundred well-spread metaphases were determinated for CAs; chromatid and isochromatid breaks (CB, IB), as well as chromatid and isochromatid exchanges (CE, IE) were determined. Gaps were not included among the aberrations.

Fifty differentially stained metaphases per donor and concentration were examined for SCE and 100 metaphases were analysed for determination of $\mathrm{M}_{1}, \mathrm{M}_{2}$ and $\mathrm{M}_{3+}$ mitotic divisions.

Statistical analysis of results were performed using the simple analysis of variance (ANOVA) and then Student's $t$-test was applied to evaluate SCEs occurrence between treated and untreated groups and also for estimation of the cell cycle delay. A $\mathrm{c}^{2}$ test was appropriated to estimate the induction of CAs, MNi and induced heterogeneity of the frequencies of the first, second and third metaphases. The proliferation indices (PI) were calculated according to Lamberti et al. (1983).

\section{Results}

The frequency of chromosomal aberrations induced by herbicide in peripheral cow lymphocyte in vitro is shown in Table 1 . Chloridazon treatments in concentrations ranging from $7 ¥ 10^{-6}$ to $7 ¥ 10^{-4} \mathrm{~mol} \cdot \mathrm{l}^{-1}$ for $24 \mathrm{~h}$ was found to induce a slight clastogenic effect in linear dose-dependent manner, reaching a statistical significance only at the highest concentration $\left(7 ¥ 10^{-4} \mathrm{~mol} \cdot \mathrm{l}^{-1}, \mathrm{p}<0.05, \mathrm{c}^{2}\right.$ test). Chromatid and isochromatid breaks were among the most common types of chromosomal alterations.

The ability of chloridazon to induce micronuclei in cytokinesis blocked cells is reflected in Table 2. A positive influence in induced $\mathrm{MN}$ frequencies was attained at the highest concentration of chloridazon $\left(7 ¥ 10^{-4} \mathrm{~mol} \cdot \mathrm{l}^{-1}, \mathrm{p}<0.01, \mathrm{c}^{2}\right.$ test $)$; both lower doses had no significant effect in the induction of $\mathrm{MN}$ differences compared to the controls.

The results obtained from the SCE assays and the lymphocyte proliferation kinetics with and without microsomal fraction are summarised in Table 3.

A $24 \mathrm{~h}$ exposure to chloridazon in the absence of S9 showed statistically significant elevations of SCE at all concentrations tested ( $p<0.05$ to 0.001 , respectively, ANOVA and Student's $t$ - test). The highest concentration $\left(7 ¥ 10^{-4} \mathrm{~mol} \cdot \mathrm{l}^{-1}\right)$ is also reflected in the reduction of the PI and in the induction of lymphocyte proliferation delays (Student's $t$-test, 
Table 1

Induction of chromosome aberrations (CA) in cow peripheral lymphocytes exposed to the herbicide chloridazon from two donors

\begin{tabular}{|c|c|c|c|c|c|c|}
\hline \multirow[t]{2}{*}{ Group } & \multicolumn{4}{|c|}{$\begin{array}{c}\text { Types of chromosomal } \\
\text { aberrations }\end{array}$} & \multirow[t]{2}{*}{$\begin{array}{c}\% \text { aberrant } \\
\text { cells }\end{array}$} & \multirow[t]{2}{*}{$\begin{array}{c}\% \text { breaks } \\
( \pm \mathrm{SD})\end{array}$} \\
\hline & $\mathrm{CB}$ & IB & $\mathrm{CE}$ & IE & & \\
\hline Control (DMSO) & 5 & - & - & - & $2.5 \pm 0.15$ & $2.5 \pm 0.15$ \\
\hline Chloridazon $\left(\mathrm{mol} \cdot \mathrm{l}^{-1}\right)$ & & & & & & \\
\hline $7 \times 10^{-6}$ & 9 & - & - & - & $4.0 \pm 0.23$ & $4.5 \pm 0.23^{\mathrm{a}}$ \\
\hline $7 \times 10^{-5}$ & 12 & - & - & - & $5.5 \pm 0.24$ & $6.0 \pm 0.26^{\mathrm{a}}$ \\
\hline $7 \times 10^{-4}$ & 17 & - & - & - & $8.0 \pm 0.34$ & $8.5 \pm 0.27 *$ \\
\hline $250 \mathrm{~m} \mathrm{~g} / \mathrm{ml}, \mathrm{EMS}$ & 13 & 4 & 7 & 3 & $13.0 \pm 0.65$ & $18.5 \pm 0.78^{* * *}$ \\
\hline
\end{tabular}

A total of 200 well-spread metaphases of each group were determined.

*, ***, $(\mathrm{P}<0.05, \mathrm{P}<0.001)-\mathrm{C}^{2}$ test

a - n. s.

$\mathrm{CB}, \mathrm{IB}$ - chromatid, isochromatid breaks, CE, IE - chromatid, isochromatid exchanges

Table 2

Induction of micronuclei $(\mathrm{MN})$ in cow lymphocyte cultures exposed to chloridazon from two donors

\begin{tabular}{|c|c|c|c|c|c|}
\hline \multirow{2}{*}{$\begin{array}{l}\text { Concentration of } \\
\text { chloridazon }\left(\mathrm{mol} \cdot \mathrm{l}^{-1}\right)\end{array}$} & \multirow{2}{*}{$\begin{array}{l}\text { Number } \\
\text { of BN }\end{array}$} & \multirow{2}{*}{$\begin{array}{l}\text { Number of } \mathrm{MN} \\
\text { in } \mathrm{BN} \text { cells }\end{array}$} & \multicolumn{2}{|c|}{ Distribution of $\mathrm{MN}$} & \multirow{2}{*}{$\begin{array}{l}\% \mathrm{MN} \\
\pm \mathrm{SD}\end{array}$} \\
\hline & & & $1 \mathrm{MN}$ & $2 \mathrm{MN}$ & \\
\hline Control (DMSO) & 2081 & 39 & 31 & 4 & $1.7 \pm 0.14$ \\
\hline $7 \times 10^{-6}$ & 2031 & $40^{\mathrm{a}}$ & 40 & - & $2.0 \pm 0.14$ \\
\hline $7 \times 10^{-5}$ & 2011 & $49^{\mathrm{a}}$ & 49 & - & $2.4 \pm 0.15$ \\
\hline $7 \times 10^{-4}$ & 2034 & $67 * *$ & 57 & 5 & $3.5 \pm 0.20$ \\
\hline $\operatorname{MMC}\left(0.4 \mathrm{~m} \mathrm{~mol}^{-1} \mathrm{l}^{-1}\right)$ & 2032 & $96 * * *$ & 82 & 7 & $5.0 \pm 0.23$ \\
\hline
\end{tabular}

**, *** - $\left(\mathrm{P}<0.01, \mathrm{P}<0.001, \mathrm{C}^{2}\right.$ test $)$

a - n. s.

$\mathrm{BN}$ - binucleated cells

Table 3

Frequency of sister chromatid exchanges (SCE) and proliferation indices in cultured cow lymphocytes exposed to the herbicide choridazon from two donors

\begin{tabular}{|c|c|c|c|c|c|}
\hline Group & $\mathrm{SCE} /$ cell & PI & Group & $\mathrm{SCE} /$ cell & PI \\
\hline without S9 & & & with S9 & & \\
\hline $\begin{array}{l}\text { Control (DMSO) } \\
\text { Chloridazon }\left(\mathrm{mol}^{-1} \mathrm{l}^{-1}\right)\end{array}$ & $7.08 \pm 2.04$ & 2.1 & $\begin{array}{l}\text { Control (DMSO) } \\
\text { Chloridazon }\left(\mathrm{mol} \cdot 1^{-1}\right)\end{array}$ & $7.02 \pm 1.73$ & 1.87 \\
\hline $7 \times 10^{-6}$ & $7.74 \pm 1.72 *$ & $2.03^{\mathrm{a}}$ & $7 \times 10^{-6}$ & $7.13 \pm 1.42^{\mathrm{a}}$ & $1.89^{\mathrm{a}}$ \\
\hline $7 \times 10^{-5}$ & $8.28 \pm 2.33 * *$ & $2.16^{\mathrm{a}}$ & $7 \times 10^{-5}$ & $7.58 \pm 2.20^{a}$ & $1.83^{\mathrm{a}}$ \\
\hline $7 \times 10^{-4}$ & $8.91 \pm 2.54 * * *$ & $1.92 *$ & $7 \times 10^{-4}$ & $8.0 \pm 2.45 *$ & $1.8^{\mathrm{a}}$ \\
\hline $\begin{array}{l}\text { Positive control } \\
0.04 \mathrm{~m} \mathrm{~g} / \mathrm{ml} \text {, } \\
\text { MMC }\end{array}$ & $17.7 \pm 8.2$ & $1.47 * * *$ & $\begin{array}{l}\text { Positive control } \\
4 \mathrm{~m} \mathrm{~g} / \mathrm{ml} \text {, } \\
\text { cyclophosphamid }\end{array}$ & $21.77 \pm 1.43^{* * *}$ & $1.75^{\mathrm{a}}$ \\
\hline
\end{tabular}

A total of 100 second - division metaphases of each group were analysed for SCE.

$*, * *, * * *(\mathrm{P}<0.05, \mathrm{P}<0.01, \mathrm{P}<0.001$, ANOVA, Student's $t$-test $)$

a - n. s.

$\mathrm{p}<0.05)$.

A similar dose-dependence was found in the SCE assay with S9 microsomal fraction. Treatments with chloridazon for 1.5 - $2 \mathrm{~h}$ caused lower frequencies of SCE than those for 
$24 \mathrm{~h}$. A significant increase of exchanges was observed only at the highest concentration ( $\left.7 ¥ 10^{-4} \mathrm{~mol} \cdot \mathrm{l}^{-1}, \mathrm{p}<0.05\right)$, while both lower doses $\left(7 ¥ 10^{-6}\right.$ and $\left.7 ¥ 10^{-5} \mathrm{~mol} \cdot \mathrm{l}^{-1}\right)$ had no positive effect in SCE increases. Also, no reduction in cell cycle kinetics was found.

\section{Discussion}

Our results give evidence of the genotoxicity of chloridazon in cultured bovine peripheral lymphocytes. A greater sensitivity in the response of lymphocytes to chloridazon exposure was obtained in the SCE assay without S9. In cultures with metabolic activation chloridazon induced lower frequencies of exchange than those seen without S9. This decrease is probably due to the short time of exposure to the herbicide. SCEs have been commonly employed in cytogenetic studies. They are considered to be available and sensitive bioindicators or biomarkers of chemical exposure, but their prediction value for assessment of adverse health consequences has been limited (Morimoto et al. 1985; Tucker and Preston 1996). Taking the sensitivity of the SCE technique into account, cultures for SCE determination were also treated with $\mathrm{S} 9$ fraction to detect possible metabolic modifications in herbicide genotoxicity.

To our knowledge there is no information on these endpoints in human or animal cells exposed to this herbicide.

The results presented here correspond to our previous finding from CA and SCE assays with chloridazon treated sheep peripheral lymphocytes in vitro (Šiviková and Dian ov ský 1997). In the CA assay with cow and sheep lymphocyte cultures, respectively, a corresponding dose dependence of induced chromosome aberrations was observed. Partial differences in the SCE assay were found. In bovine peripheral lymphocytes the lowest dose of herbicide caused a significant increase in SCE frequencies $\left(7 ¥ 10^{-6} \mathrm{~mol} \cdot \mathrm{l}^{-1}, \mathrm{P}<0.05\right)$, but damage induced by the same dose in sheep lymphocytes show no statistical significance. The higher test concentrations had the same positive effect in lymphocytes of both species. With regard to the cell cycle kinetics, exposure to herbicide for $24 \mathrm{~h}$ at a concentration of $7 ¥ 10^{-4} \mathrm{~mol} \cdot \mathrm{l}^{-1}$ caused a slight cytotoxic effect in cow, measured as proliferation delay $(\mathrm{P}<0.05$, Student's $t$-test $)$ that was not seen in sheep cultures.

Significant increase in $\mathrm{MN}$ frequencies after treatment with the highest dose of chloridazon $(\mathrm{P}<0.01)$ was probably due to a longer time of exposure to herbicide.

The cytogenetic analysis revealed that donor 2 had been a carrier of a relatively frequent aberration in several cattle breeds - the Robertsonian translocation 1/29 [59, XX, rob (1;29)]. There was no cause described to give rise to this aberration de novo.

The spontaneous frequency of SCEs in the donor with normal karyotype (donor 1) was a little different from those seen in the donor 2 - with the Robertsonian translocation (7.0 or $7,15 \mathrm{SCEs} /$ cell in cultures without $\mathrm{S} 9$ and 6.93 or $7.12 \mathrm{SCE} /$ cell in cultures with S9, respectively). Popescu (1978) described similar differences in cattle with normal karyotype and one bull with the same translocation. The basal mean of SCEs and CAs as well as the individual sensitivity of blood lymphocytes to herbicide exposure for $24 \mathrm{~h}$ between both donors is shown in Fig. 1. Differences in the MN frequency are not given in Figure because of prolonged sampling time. In spite of different donors' karyotypes variability in CA and SCE frequencies are not considered as substantial. The mean in SCE frequency and individual sensitivity to genotoxic agents is widely described by several investigators. Those can be caused by genetic and environmental factors (Catalan et al. 1995) and/or culture conditions (namely by the presence of BrdU in medium, Morales Ramirez et al. 1987). Our cultures were performed with BrdU at a final concentration of $8 \mu \mathrm{g} / \mathrm{ml}$ of medium. Catalan et al. (1995) observed increased frequencies of SCE in cattle at $15 \mu \mathrm{g} / \mathrm{ml}$ of BrdU concentration. There is also a report confirming that chromosome 1 in cattle has been very sensitive to BrdU - labeling (Iannuzzi et al. 1991). Similarly, 


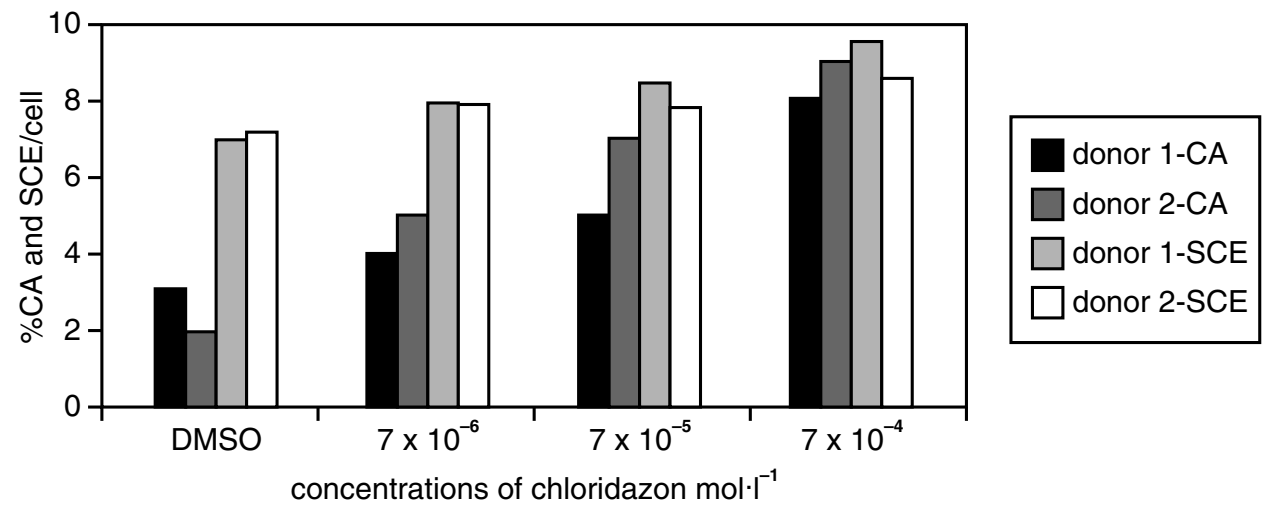

Fig. 1. Individual differences in CA and SCE frequencies between donors with normal and abnormal karyotype

Popescu (1978) demonstrated that the exchange frequency was not changed on the chromosome of the 1/29 translocation compared to those of free homologues. In conclusion, our results indicate genotoxic effects in cultured bovine lymphocytes. A greater sensitivity in detection of chloridazon genotoxicity was obtained in the SCEs assay. In comparison with sheep lymphocytes, experiments presented with bovine peripheral lymphocytes showed also a weak cytotoxic influence of the herbicide.

\section{Chromozómové poškodenia indukované herbicídom chloridazonom v kultivovaných periférnych lymfocytoch hovädzieho dobytka}

Hodnotili sme schopnosṫ herbicídu chloridazon zvýšit frekvencie mikrojadier (MN), chromozómových aberácií (CA) a sesterských chromatidových výmen (SCE) v kultivovaných periférnych lymfocytoch hovädzieho dobytka, a tiež jeho vplyv na kinetiku bunkového cyklu. Možnú metabolickú modifikáciu v genotoxicite herbicídu sme v teste pre determináciu SCE študovali ovplyvnením kultúr S9 frakciou.

Signifikantné zvýšenie CA a MN sme zistili po aplikácii chloridazonu v koncentrácii $7 ¥ 10^{-4} \mathrm{~mol} \cdot \mathrm{l}^{-1}(\mathrm{P}<0.05$, resp. $\mathrm{P}<0.01)$, nižšie dávky herbicídu $\left(7 ¥ 10^{-5}\right.$ a $\left.7 ¥ 10^{-6} \mathrm{~mol} \cdot \mathrm{l}^{-1}\right)$ neboli štatisticky významné. Jasnú dávkovú závislost̉ a štatisticky významné zvýšenie indukovaných chromozómových poškodení sme pozorovali v SCE teste bez použitia S9 frakcie. Najvyššia koncentrácia herbicídu sa prejavila redukciou proliferačného indexu a indukciou slabého oneskorenia proliferácie.

Tieto pozitívne výsledky tiež informujú o možnosti zvýšenia genetického rizika pre človeka prostredníctvom potravinového retazca.

\section{Acknowledgments}

This work was supported by the Ministry of Education and Science of the Slovak Republic (Research Project No. 1/ 5150/98).

\section{References}

ALMÁSSY, Z., KREPINSKY, A. B., BIANCO, A., KOTELES, G. J. 1987: The present status and perspectives of micronucleus assay in radiation protection. A review. Appl. Radiat. Isotop. 38: 241- 249

CATALAN, J., MORENO C., ARRUGA, M. V. 1995: Sister - chromatid exchanges in cattle: breed, sex and BrdU dose effects. Mutat. Res. 331: 205-221

CORBETT, J. R, WRIGHT, K., BAILLIE, A. C. 1984: The Biochemical Mode of Action of Pesticides. $2^{\text {nd }}$ ed. Academic Press, London, 50-92

CREMLYN, R. 1978: Pesticides - Preparation and Mode of Action. In Herbicides (R. Cremlyn Ed.), pp. 140-172. John Wiley and Sons, Ltd, Chichester. 
DOLARA, P., SALVADORI, M., CAPOBIANCO, T., TORRICELLI, F. 1992: Sister chromatid exchanges in human lymphocytes induced by dimethoate, omethoate, deltamethrin, benomyl and their mixture. Mutat. Res. 283: $113-118$

HADAČ, E. 1989: Xenobiotics influencing an environment and a balance of biosphere. In: Proceedings ,, Cizorodé látky v zemědělství" ČSVTS, Brno, 18-23 (In Czech.)

HRELIA, P., MAFFEI, F., FIMOGNARI, C., VIGAGNI, F., CANTELLI-FORTI, G. 1996: Cytogenetic effects of Metalaxyl on human and animal chromosomes. Mutat. Res. 369: 81-86

IANNUZZI, L., DI MEO, G. P., PERUCATTI, A., FERRARA, L., GUSTAVSSON, I. 1991: Sister chromatid exchange in chromosomes of cattle from three different breeds reared under similar conditions. Hereditas 114: 201-205

LAMBERTI, L., PONZETTO, B. P., ARDITO, G. 1983: Cell kinetics and sister chromatid exchange frequency in human lymphocytes. Mutat. Res. 120: 193-199

MARON, D. M., AMES, B. N. 1983: Revised methods for the Salmonella mutagenicity test. Mutat. Res. 113: 173-215

MORALES - RAMIREZ, P., RODRIGUEZ - REYES, R., VALLARINO - KELLY, T. 1987: Analysis of spontaneous sister - chromatid exchanges in vivo by three-way differentiation. Mutat. Res. 178: 49-56

MORIMOTO, K., SATO-MIZUNO, M., KOIZUMI, A. 1985: Sister-chromatid exchanges and cell-cycle kinetics in human lymphocyte cultures exposed to alkylating mutagens: apparent deformity in dose-response relationships. Mutat. Res. 152: 187-196

POPESCU, C. P. 1978: Sister chromatid exchanges (S.C.E.) in normal and abnormal bovine (Bos taurus L.) karyotypes. Cytologia 43, 533-540

PERRY, P., WOLFF, S. 1974: New Giemsa methods for differential staining of sister chromatids. Nature 251: 156-158

RIBAS, G., SURRALlES, J., CARBONELL, E., XAMENA, N., CREUS, A., MARCOS, R. 1996a: Genotoxicity of the herbicides alachlor and maleic hydrazide in cultured human lymphocytes. Mutagenesis 11: 221-227

RIBAS, G., SURRALLES, J., CARBONELL, E., XAMENA, N., CREUS, A., MARCOS, R. 1996b: Genotoxic evaluation of the herbicide trifluralin on human lymphocytes exposed in vitro. Mutat. Res. 371: 15-21

SURALlÉS, J., XAMENA, N., CREUS, A., CATALÁN, J.,NORPPA, H., MARCOS, R. 1995: Induction of micronuclei by five pyrethroid insecticides in whole-blood and isolated human lymphocyte cultures. Mutat. Res. 341: $169-184$

ŠIVIKOVÁ, K., DIANOVSKÝ, J. 1997: Cytogenetic effects of the herbicide chloridazon in cultured sheep lymphocytes. Acta Vet. Hung. 45: 11-16

TUCKER, J. D., PRESTON, R. J. 1996: Chromosome aberrations, micronuclei, aneuploidy, sister chromatid exchanges, and cancer risk assessment. Mutat. Res. 365: 147-159

WATT, J. L., STEPHEN, G. S. 1986: Lymphocyte culture for chromosome analysis. In Human Cytogenetics, a Practical Approach (D. E. Rooney and B. H. Czepulkowski, Eds.), pp. 39-55. IRL Press, Oxford.

WOO, Y.-T, LAI, D. Y., ARGUS, M. F., ARCOS, J. C. 1996: Carcinogenicity of organophosphorus pesticides / compounds: An analysis of their structure - activity relationships. Environ. Carcino. Ecotox. Revs. C14, (1): 1-42 